\title{
Effects of Content-Based Instruction on English Language Performance of Thai Undergraduate Students in a Non-English Program
}

\author{
Patchara Vanichvasin ${ }^{1}$ \\ ${ }^{1}$ Faculty of Education, Kasetsart University, Bangkok, Thailand \\ Correspondence: Patchara Vanichvasin, Faculty of Education, Kasetsart University, Bangkok, Thailand.
}

Received: June 1, 2019 Accepted: July 1, 2019 Online Published: July 3, 2019

doi: 10.5539/elt.v12n8p20 URL: https://doi.org/10.5539/elt.v12n8p20

\begin{abstract}
The research purposes were to: 1) develop lesson plans for content-based instruction; 2) evaluate the students' perceptions of the effectiveness of content-based instruction; and 3) investigate the effects of content-based instruction on English language performance of Thai undergraduate students in a non-English program. The sample group was 19 Thai undergraduate students. The research instruments were: 1) lesson plans for content-based instruction; 2) an evaluation form of lesson plans; 3) an effectiveness questionnaire on content-based instruction; and 4) English language performance tests. Data were analysed the mean, standard deviation, content analysis and a t-test. The research results were: 1) the lesson plans were developed and evaluated by experts as applicable for use at a high level and pilot-tested with 14 non-targeted Thai undergraduate students with the perceived effectiveness at a high level; 2) the 19 targeted Thai undergraduate students perceived the content-based instruction as an effective methodology and essential aid in generating opportunities to use English at a high level. They thought that it was fun and helped them practice, have a better attitude and gain more courage to express themselves in English; and 3) the post-course English language performance were significantly $(\mathrm{P}<0.05)$ higher than the pre-course English language performance. In conclusion, content-based instruction produced positive results and could be used as an effective methodology and essential aid in generating opportunities to use English, which resulted in increased English language performance.
\end{abstract}

Keywords: content-based instruction, effects, English language performance, non-English program

\section{Introduction}

\subsection{Statement of the Problem}

The promotion of English learning has become an urgent and vital development issue for Thailand (Doungphummes \& Chandransu, 2016) since English is regarded as an essential skill for the globalized economy by governments, which devote considerable resources to its teaching in formal education, though often with limited success in terms of achievements (Hayes, 2016). In addition, the increasing emphasis on and investment in English language teaching in Thailand does not seem to have resulted in increased language proficiency as assessed by the National Institute of Education Testing (Trakulphadetkrai, 2011). It seemed that there are faults in teaching and learning the language (Napat, 2014) because current pedagogical approaches are not able to help learners become competent English users (Kongkerd, 2013) and average Thai students who have graduated from university have studied English for as many as 15 years (Hayes, 2016) but their English language performance were still questionable. Also, it was found that the English curriculum in Thai universities in its current form can not meet the demands for English as used in the workplace (Wiriyachitra, 2001).

At present, Thailand has focused on communicative language teaching as the key approach to improve communicative competence but in reality, giving opportunities to students to use as much English as they can in real life contexts should be critically and equally considered, especially for Thai students who have limited chances not only to be exposed to native English speakers, but also the opportunity to use English in their real life settings (Poonpon, 2011). The question is how many opportunities do students have to use English in class (Jantarach, 2009). Students in an English program definitely have more opportunities to use English on many more occasions than those who are outside such programs while English was required by both groups of students 
either in an English program or non-English program.

Instructional methodologies to enhance the English language performance of Thai students have been widely and extensively researched in various contexts to find the best methodologies that can truly enhance English language performance. Content-based instruction is considered as one of the effective instructional methodologies (Wesche, 1993; Stryker \& Leaver, 1997; Klee \& Tedick, 1997; Marani, 1998; Davies, 2003; Heo, 2006) because it uses English as a medium to teach content knowledge while generating multiple opportunities for students to use English in class. Therefore, the use of English stems from meaningful purposes (content learning) and frequent practice (opportunities to use English). This is in accordance with Stoller (2002) who stated that language is viewed as a medium for learning content and content as a resource for learning and improving language. Walters et al. (2005) suggested that teachers should teach English by creating classroom environments to include opportunities to speak so students can practice speaking more fluently while Stoller (2004) believed that with content-based instruction, students are provided with many opportunities for language production. Therefore, it is considered by many researchers as an effective and realistic methodology in terms of combining language and content learning $(\mathrm{Heo}, 2006)$ through the essential features of learning a language with academic content, engaging in activities, developing proficiency in academic discourse, and fostering the development of effective learning strategies (Crandall, 1999).

Ample studies based on content-based instruction have demonstrated positive results (Stoller, 2002; Song, 2006; Corrales \& Maloof, 2009; Amiri \& Fatemi, 2014). However, empirical data need to be gathered to determine the effectiveness of content-based programs in different situations (Brinton, Snow, \& Wesche, 2003). In the Thai educational context, much research has been related to content-based instruction (for example, Wuthisawangwong, 2016; Srichaiwong \& Maneekul, 2017; Khruawan \& Dennis, 2017) but most of it has focused on primary and secondary education. Only a few research projects have focused on higher education although English requirement was demanded as one of criteria in attaining jobs after graduation and was considered as a tool for personal economic advancement (Hayes, 2014). Therefore, more empirical data are needed to add to the existing knowledge of content-based instruction in higher education in Thailand.

Due to the significance of English, appropriate English instruction and the limited research on content-based instruction in higher education in Thailand, the current study used content-based instruction as an instructional methodology to enhance English language performance of Thai undergraduate students. It was hypothesized that the content-based instruction was developed, tried out, and tested and their results could provide a better understanding of content-based instruction, help teachers make better decisions in teaching English much more effectively and be served as guidelines for developing content-based learning experiences in a way that truly builds English language performance of Thai undergraduate students in higher education.

\subsection{Literature Review}

Content-based instruction (CBI) is considered as one of the instructional methodologies in developing English language performance. Teaching in this approach is organized around the content and the priniciples of content-based instruction are heavily rooted on the priniciples of communicative language teaching since they involve an active participation of students in the exchange of content (Villalobos, 2013).

Leaver and Stryker (1989) defined it as an approach in which language proficiency is achieved by shifting the focus from the learning of language to the learning of subject matter while Brinton, Snow and Wesche (2003, 1989 ) and Met (1999) defined it as the integration of language and content instruction, which concentrates on the content rather than the language with its aims to teach academic subject matter but at the same time gain second language skills. Teaching English is organized around the content rather than around a linguistic type of syllabus (Richards \& Rodgers, 2014). With content-based instruction, students learn language and content at the same time, each supporting the development of the other (Lyster, 2007) as Snow and Kamhi-Stein (2002) stated that language is learned best as a vehicle of instruction, not as the object of instruction.

The models of CBI vary in design and implementation based on setting, level, and the nature of instruction. Some models have proved successful at the elementary school level whereas some have demonstrated their effectiveness at secondary or post-secondary levels. Some models emphasize the content but in some models more emphasis is put on language (Duenas, 2004) and some models have the same instructor whereas some have different instructors. However, in general, there are three content-based instruction models, namely, theme-based language instruction, sheltered content instruction, and adjunct language instruction. First, theme-based language instruction is the model that the course was taught by a language instructor and was structured around topics or themes, with the topics forming the backbone of the course curriculum (Brinton, Snow, \& Wesche, 2003). Its primary purpose is to help students develop second language competence within specific topic areas. The topics 
chosen can be several unrelated topics or one major topic. Language instructors are responsible for language and content instruction (Brinton et al., 1989). Second, sheltered content instruction is the model that the content course is taught in the second language to a segregated group of learners by a content area expert, such as university professor who is a native speaker of the target language (Brinton, Snow, \& Wesche, 2003) or a language teacher with content-area knowledge (Gaffield-Vile, 1996). Third, adjunct language instruction is the model that students take part in two linked courses, a content course and a language course both of which include the same content in common and complement each other regarding jointly coordinated homework (Richard \& Rodgers, 2014). The rationale of this model is that the linked courses can assist students developing academic coping strategies and cognitive skills which can be transferred to other discipline (Brinton et al., 1989).

All models are built under similar theoretical rationales provided by Snow, Met, and Genesee (1989) who suggested that language was learned most effectively in meaningful, purposeful, social, and academic contexts and content learning provides the basis for language learning. This means that the language is considered the medium through which new content is learned. While learning, learners will acquire competency naturally. The language being learned is taught within the context of the content (Genesee, 1994). The learners, meanwhile, can improve their language learning alongside learning about the content. This approach places greater emphasis on the content being learned than on the language (Brinton, Snow, \& Wesche, 1989). Students are exposed to a considerable amount of language while learning content, students are taught useful language that is embedded within relevant discourse contexts rather than isolated language fragments (Grabe \& Stoller, 1997).

However, there are some considerations according to Crandall (1999) who suggested that the content-based instruction can be used in various ways depending on the skills being taught and includes not only traditional teaching methods such as grammar-based instruction or vocabulary development but also contemporary approaches such as communicative language teaching and humanistic methods but it needs to include the essential features of learning a language with academic content, engaging in activities, developing proficiency in academic discourse, and fostering the development of effective learning strategies.

It is evident that content-based instruction has high potential for use as an English instruction. With this methodology, English is not learned through direct instruction but rather indirect instruction by using English as a medium and students can benefit from both content and English learning at the same time. However, there is preparation for successful implementation of content-based instruction in classroom to be considered.

\section{Method}

This research was an experimental research with pre-test and post-test design before and after the implementation of content-based instruction. Before the implementation, the lesson plans for content-based instruction were developed from the characteristics of content-based instruction gained from the literature review, validated by experts and pilot tested by 14 Thai undergraduate students. Results and comments were used to improve the developed lesson plans for content-based instruction. Next, the developed lesson plans for content-based instruction were implemented in a communication skills course with 19 Thai undergraduate students for 15 sessions over one semester, in which the first session was the introduction of content-based instruction, and pre-tests, while the last session was post-tests. The instructor used content-based instruction to teach the course for 13 sessions.

\subsection{Participants}

The participants were 19 Thai undergraduate students who enrolled in semester two of a bachelor-level course on communication skills. Students were selected based on the purposive sampling method as they enrolled in the selected course employing content-based instruction.

\subsection{Instruments}

The research instruments consisted of: lesson plans for content-based instruction, an evaluation form of lesson plans, an effectiveness questionnaire on the use of content-based instruction and English language performance tests as detailed below.

Lesson plans for content-based instruction were developed from the existing lesson plans for 15 weeks to integrate language and content teaching. They were evaluated by 3 experts, who were faculty members in the faculty of education with strong expertise in the field of teaching and learning and pilot tested by 14 non-targeted undergraduate students, who were studying in the Business and Computer Education program and enrolled in the Communication Skills course like the targeted students.

An evaluation form of lesson plans was used for collecting experts' opinions towards the applicability of the developed lesson plans for content-based instruction before its use. The researcher developed it based on the key 
components of a lesson plan. It contained 12 multiple-choice items with a 5-unit Likert-type rating scale from very low to very high applicability. Comments and suggestions from one open-ended question were summarized and reported. Results of scores, comments, and suggestions were considered for improvement before using the developed lesson plans to teach the course.

An effectiveness questionnaire was used to collect students' perceptions towards the effectiveness of content-based instruction. The researcher developed it based on the key components of content-based instruction. It contained 10 multiple-choice items with a 5-unit Likert-type rating scale from very low to very high effectiveness with values of the index of congruence (IOC) between 0.67 and 1.00 according to experts, and a reliability (coefficient alpha technique) value of 0.80 when pilot-tested with 14 non-targeted students.

English language performance tests, used pre-course and post-course with the same item order, were developed from the content of communication skills course by the researcher to investigate the effects of the content-based instruction on English language performance in reading, writing, speaking, and listening before and after the course. The tests each consisted of 15 multiple-choice items worth one score each with only one correct answer per question to investigate reading performance, two short answer questions worth 10 scores each to investigate writing performance, 15 listening activities worth one score each to investigate listening performance, and 10 situations worth two scores each to investigate speaking performance. Summing-up all items yielded the final scores ranging from 0 to 70 indicating English language performance. The maximum total score was 70.3 experts checked the validity of each test with values of the index of congruence (IOC) between 0.67 and 1.00 . The tests were tried out with 14 non-targeted students with reliability values (coefficient alpha technique) values of 0.891 for multiple choices, 0.989 for short answers, 0.855 for listening activities, and 0.945 for situations. The researcher analysed its difficulty and discrimination and selected the items presenting a level of difficulty $(\mathrm{P})$ between 0.20 and 0.80 and discrimination (r) between $0.20-1.00$.

\subsection{Data Collection}

The targeted students attended the pre-tests of English language performance. After the pre-tests, the researcher, as a teacher, used the developed lesson plans for content-based instruction, which were evaluated by experts and pilot tested by non-targeted students, to teach the communication skills course. After targeted students completed the course, they were given the post-tests of English language performance at the end of course to investigate effects on their English language performance, and the effectiveness questionnaire based on the course implementation of content-based instruction to evaluate their perceptions of the effectiveness of content-based instruction. Finally, all instruments distributed were checked for completeness and accuracy.

\subsection{Data Analysis}

Both qualitative and quantitative approaches were applied. Different scoring rubrics using a rating scale, ranging from 1 (very low) to 5 (very high) were used to assess the applicability from experts' opinions and the effectiveness of content-based instruction from students' perceptions of non-targeted and targeted students. The t-test statistic was used to compare the results of English language performance between pre-and post-testing. Content analysis was used to identify further recommendations retrieved from experts' opinions and thoughts on the content-based instruction retrieved from students' perceptions. The obtained data were analyzed using mean, standard deviation, content analysis, and a t-test, in which the $\mathrm{P}$ value was set at the 0.05 level of significance.

\section{Results and Discussion}

The research results were presented as following.

\subsection{Development of Lesson Plans for Content-Based Instruction}

Lesson plans for content-based instruction were developed from a regular communication skills course with dual focus on subject matter and English learning according to the literature review of lesson planning. The researcher selected 13 topics, namely, the overview of communication, internal and external communication, definition, process, types, verbal and nonverbal communication, factors affecting communication, communication styles, communication skills, listening skills, reading skills, speaking skills and writing skills. All topics were sequenced according to the course syllabus. Next, the researcher adopted sheltered content-based instruction, in which the course content was taught by the researcher, as an instructor with two roles of being a subject matter expert in the communication skills course and a language teacher with content-area knowledge to teach the course in English. Students were encouraged to play an active role in studying the content and learning the language at the same time. The course was divided into 15 sessions to include introduction, topics, and tests. Exsiting slides and handouts were updated and translated into English. 13 topics, as lessons to learn, were planned according to the standard components and accordance of lesson plans covering learning objectives, 
content knowledge, learning activities, teaching aids, assessment and the accordance of all components. The results of the applicability before the implementation of content-based instruction are shown in Table 1 .

Table 1. Mean and standard deviation of applicability according to experts' opinions

\begin{tabular}{|c|c|c|c|}
\hline Applicability for Use & $\overline{\mathrm{X}}$ & S.D. & Interpretation \\
\hline \multicolumn{4}{|l|}{ Learning objectives } \\
\hline 1. Learning objectives emphasize developing English competencies & 4.00 & 0.00 & High \\
\hline 2. Learning objectives emphasize generating opportunities to use English in class & 5.00 & 0.00 & Very High \\
\hline \multicolumn{4}{|l|}{ Content knowledge } \\
\hline 3. Content in English is comprehensible & 4.00 & 0.00 & High \\
\hline 4. Content in English is related to the course & 4.33 & 0.58 & High \\
\hline \multicolumn{4}{|l|}{ Learning activities } \\
\hline 5. Learning activities are various & 4.33 & 0.58 & High \\
\hline 6. Learning activities are interesting & 4.00 & 0.00 & High \\
\hline 7. English is used in learning activities & 4.67 & 0.58 & Very High \\
\hline \multicolumn{4}{|l|}{ Teaching aids } \\
\hline 8. Teaching aids are various & 4.33 & 0.58 & High \\
\hline 9. Teaching aids are in English & 4.67 & 0.58 & Very High \\
\hline \multicolumn{4}{|l|}{ Assessment } \\
\hline 10. Assessment is clear and consistent & 4.33 & 0.58 & High \\
\hline $\begin{array}{l}\text { 11.Assessment gives information about English language performance and } \\
\text { improvement }\end{array}$ & 4.33 & 0.58 & High \\
\hline \multicolumn{4}{|l|}{ Accordance of all components } \\
\hline $\begin{array}{l}\text { 12. Learning objectives, content knowledge, learning activities, teaching aids, and } \\
\text { assessment are in accordance throughout the developed lesson plans }\end{array}$ & 4.33 & 0.58 & High \\
\hline Total & 4.36 & 0.27 & High \\
\hline
\end{tabular}

Table 1 shows that the overall mean was 4.36 and the standard deviation (S.D.) was 0.27 , which was at the high level. In particular, the mean scores and standard deviation of learning objectives, content knowledge, learning activities, teaching aids, assessment, and accordance of all components were at high levels $(\overline{\mathrm{X}}=4.50$, S.D. $=0.00$; $\overline{\mathrm{x}}=4.17$, S.D. $=0.29 ; \overline{\mathrm{x}}=4.33$, S.D. $=0.33 ; \overline{\mathrm{x}}=4.50$, S.D. $=0.00 ; \overline{\mathrm{x}}=4.33$, S.D. $=0.58 ; \overline{\mathrm{x}}=4.33$, S.D. $=0.58$, respectively). The lesson plans for content-based instruction were pilot tested with 14 non-targeted students with the perceived effectiveness at a high level $(\overline{\mathrm{x}}=4.29$, S.D. $=0.37)$. Correction of some ambiguous or difficult English wording was recommended by experts and the respective changes were made before next use.

\subsection{Student's Perceptions of the Effectiveness of the Content-Based Instruction}

The developed lesson plans for content-based instruction were used to teach the communication skills course in classroom over a period of 15 sessions. The researcher, as an instructor, introduced the content-based instruction at the beginning of first session, explained the purposes of the study, and invited students to participate in the study. Before starting content-based instruction, students were given pre-tests. Each topic was taught for three hours session. English was used as a medium to study, communicate and evaluate English language performance of students. All students attended classes using content-based instruction and were encouraged to participate actively and practice English frequently by engaging in a variety of learning activities such as discussions, presentations and situation-based games in their learning process. At the end of course, students were given post-tests to measure their English language performance before and after the implementation of content-based instruction and an effectiveness questionnaire to measure their perception of the effectiveness of the content-based instruction. Students' perceptions towards the effectiveness of content-based instruction are shown in Table 2. 
Table 2. Mean and standard deviation of students' perceptions towards the effectiveness

\begin{tabular}{llll}
\hline Students'perceptions & $\overline{\mathrm{X}}$ & S.D. & Interpretation \\
\hline Effective instructional methodology & & & \\
1. Content-based instruction enhances English language performance & 4.16 & 0.60 & High \\
2. English used in instruction is comprehensible & 4.42 & 0.51 & High \\
3. An instructor communicates in English & 4.53 & 0.51 & Very High \\
4. English used in classroom is meaningful & 4.11 & 0.46 & High \\
5. Learning strategies are effective and systematic & 4.53 & 0.70 & Very High \\
6. Assessment is done systematically & 3.79 & 0.71 & High \\
7. English is used as a medium in classroom & 4.42 & 0.61 & High \\
Essential aid in generating opportunities to use English & & & \\
8. Opportunities to use English were provided & & & \\
in many occasions throughout the course & 4.16 & 0.69 & High \\
9. Students are given opportunities to use English & 4.21 & 0.71 & High \\
10. The use of English is promoted at all times & 4.37 & 0.60 & High \\
Total & 4.27 & 0.38 & High \\
\hline
\end{tabular}

Table 2 shows that students perceived the effectiveness of content-based instruction at a high level $(\bar{x}=4.27$, S.D. $=0.38$ ). In particular, they perceived the content-based instruction as an effective methodology and as an essential aid in generating opportunities to use English at high levels $(\overline{\mathrm{x}}=4.28$, S.D. $=0.36$ and $\overline{\mathrm{x}}=4.25$, S.D. $=$ 0.49 , respectively). Students thought that it was fun and a good way of developing English language performance through frequent opportunities to practice English, resulting in a better attitude and more courage to express themselves in English.

\subsection{Effects of the Content-Based Instruction on English Language Performance}

English language performance tests were used to investigate the effects of the content-based instruction on English language performance of Thai undergraduate students. Their validity and reliability were checked by 3 experts with the index of congruence (IOC) values more than 0.60 and pilot tested with non-targeted students with the value of Cronbach's alpha more than 0.80 . All tests were assigned to students before and after the implementation of content-based instruction to collect data. Dependent Sample T-test was then used to compare the means between the two related groups on two occasions for the same continuous dependent variable (English language performance) and to examine whether there was a statistical difference between the means of English language performance before and after implementing the content-based instruction. Assumption checking was carried out prior to statistical procedures. No missing data or significant outliers in the differences between the two related groups were found. The distribution of the differences in the dependent variable was normally distributed. Assumptions were met for both the pre-and post-test scores of the two related groups and their testing indicated no violation of assumptions. Table 3 illustrates English language performance in the pre-tests and post-tests of targeted subjects.

Table 3. English language performance before and after implementing the content-based instruction

\begin{tabular}{llllll}
\hline English Language Performance & Total Score & $\overline{\mathrm{X}}$ & S.D. & t-test & Sig* \\
\hline Pre-test & 70 & 41.26 & 5.05 & \multirow{2}{*}{$27.83^{*}$} & 0.00 \\
Post-test & 70 & 61.16 & 4.59 & & \\
\hline
\end{tabular}

According to Table 4, the mean score of the pre-test was 41.26 (S.D. $=5.05)$. After implementation, the mean score increased to 61.16 (S.D. $=4.59$ ). The post-course English language performance was much higher than pre-course English language performance at the 0.05 significance level.

In particular, English language performance in reading, writing, listening and speaking was demonstrated in 
Table 4, 5, 6 and 7. After the implementation of content-based instruction, the highest performance was listening and the lowest performance was speaking, which was in accordance with Jaiyai, Torwong, Usaha, Danvirattana, Luangthongkam \& Piyadamrongchai (2005) who reported that many Thai students could not use English skills effectively, especially speaking while the most improved performance was reading performance, which was in accordance with Anyadubalu (2010) who reported that Thai students are more capable to read English better than understanding and speaking the language. Therefore, it was suggested that the emphasis on enhancing speaking performance should be increased with more frequency while the use of reading, writing and listening performance should be included and encouraged but not strongly emphasized as much as speaking performance.

Table 4. Reading performance before and after using the content-based instruction

\begin{tabular}{llllll}
\hline Reading performance & Total Score & $\overline{\mathrm{x}}$ & S.D. & t-test & Sig* \\
\hline Pre-test & 15 & 7.58 & 1.12 & \multirow{2}{*}{$16.19^{*}$} & 0.00 \\
Post-test & 15 & 13.42 & 0.90 & & \\
\hline
\end{tabular}

*The mean difference is significant at the 0.05 level.

According to Table 4, the mean score of the pre-test in students' reading performance was 7.58 (S.D. $=1.12$ ). After implementation, the mean score increased to $13.42($ S.D. $=0.90)$. The post-course reading performance was much higher than pre-course reading performance at the 0.05 significance level.

Table 5. Writing performance before and after using the content-based instruction

\begin{tabular}{llllll}
\hline Writing performance & Total Score & $\overline{\mathrm{X}}$ & S.D. & t-test & Sig* \\
\hline Pre-test & 20 & 12.00 & 1.80 & \multirow{2}{*}{$13.87^{*}$} & 0.00 \\
Post-test & 20 & 17.63 & 2.04 & & \\
\hline
\end{tabular}

*The mean difference is significant at the 0.05 level.

According to Table 5, the mean score of the pre-test in students' writing performance was 12.00 (S.D. $=1.80$ ). After implementation, the mean score increased to 17.63 (S.D. $=2.04$ ). The post-course writing performance was much higher than pre-course writing performance at the 0.05 significance level.

Table 6. Listening performance before and after using the content-based instruction

\begin{tabular}{llllll}
\hline Listening performance & Total Score & $\overline{\mathrm{x}}$ & S.D. & t-test & Sig* $^{*}$ \\
\hline Pre-test & 15 & 9.37 & 1.38 & \multirow{2}{*}{$27.83^{*}$} & \multirow{2}{*}{0.00} \\
Post-test & 15 & 13.79 & 1.03 & & \\
\hline
\end{tabular}

*The mean difference is significant at the 0.05 level

According to Table 6, the mean score of the pre-test in students' listening performance was 9.37 (S.D. $=1.38$ ). After implementation, the mean score increased to 13.79 (S.D. $=1.03$ ). The post-course listening performance was much higher than pre-course listening performance at the 0.05 significance level.

Table 7. Speaking performance before and after using the content-based instruction

\begin{tabular}{llllll}
\hline Speaking performance & Total Score & $\overline{\mathrm{X}}$ & S.D. & t-test & Sig* \\
\hline Pre-test & 20 & 11.79 & 1.93 & \multirow{2}{*}{$12.12^{*}$} & 0.00 \\
Post-test & 20 & 16.68 & 2.43 & & \\
\hline
\end{tabular}

*The mean difference is significant at the 0.05 level. 
According to Table 7, the mean score of the pre-test in students' speaking performance was 11.79 (S.D. $=1.93$ ). After implementation, the mean score increased to 16.68 (S.D. $=2.43$ ). The post-course speaking performance was much higher than pre-course speaking performance at the 0.05 significance level.

All results pointed out that the content-based instruction had effects on students' English language performance in reading, writing, listening and speaking because students were taught with the effective English instruction and were given multiple opportunities to use as much English as they can in the course. Clearly, students had higher scores due to the fact that the content-based instruction created a learning environment where English was used as a medium to teach meaningful content and generated multiple opportunities to use English through topics and tests. As a result, their English language performance was significantly improved when the content-based instruction was implemented to create a learning environment suitable for language and content development in order to build content-based learning experiences for students to perform and practice English meaningfully and frequently.

The main finding showed that content-based instruction was an effective instructional methodology according to student's perceptions and students performed better after its' implementation. Therefore, using content-based instruction to teach the course was powerful in enhancing English language performance, as the research results demonstrated that students had higher scores after implementing content-based instruction. The findings were in line with Adawiyah (2018), Stoller (2002), Corrales and Maloof (2009), Heo (2006), and Song (2006) who reported that the content-based instruction was effective in developing language and led to a significant improvement in language proficiency while Dupuy (2002) stated that the content-based instruction provides students with ample opportunities to interact. In reality, lack of opportunities to use English was one of obstacles that Thai students were facing and one of the reasons Thai students do not want to learn was that the teaching methodology in the classroom is not interesting (Punthumasen, 2007). This study was also in accordance with many research findings in Thailand, which have also demonstrated that content-based instruction contributes to English proficiency (Wuthisawangwong, 2016; Srichaiwong \& Maneekul, 2017; Khruawan \& Dennis, 2017). Therefore, the current study can provide a better understanding of content-based instruction as a powerful instruction methodology and systematic guidelines for using it to generate English learning experiences in a way that helps build English language performance in higher education in Thailand. With content-based instruction, the future of the English language performance of Thai undergraduate students may become brighter and meet the demands for English requirement in the workplace.

\section{Conclusion and Recommendation}

It can be concluded that the use of content-based instruction contributed to improved English language performance of Thai undergraduate students as it can help them learn English and performed better. Therefore, content-based instruction can be considered for use as an effective instructional methodology and an essential aid in generating multiple opportunities to use English if meaningful topics and frequent practice were included. As a result, teaching English alone would not be sufficient if it lacked opportunities to use the English learned or there was a serious hindrance to practicing the English. To successfully implement content-based instruction in the classroom, teachers have to play an important role in taking essential features of content-based instruction into account, supplying meaningful topics, creating appropriate learning environment and engaging students in a variety of learning activities such as discussions, presentation and situation-based games to offer multiple opportunities for students to participate and practice English frequently as seen in the study.

However, the current research was on a small scale so it is suggested future study should use students in a non-English program based on a larger scale and using a control and experimental group of samples may give a clearer result to ensure that content-based instruction can truly create a supportive and positive English learning environment, which leads to increased English language performance at the end.

\section{References}

Adawiyah, R. (2018). The Effectiveness of Content Based Instruction in Teaching Speaking Skill For EFL Learners. Voices of English Language Education Society, 2(2), 105-112. https://doi.org/10.29408/ veles.v2i 2.846

Amiri, M., \& Fatemi, A. H. (2014). The Impact of Content-based Instruction on Students' Achievement in ESP Courses and their Language Learning Orientation. Theory and Practice in Language Studies, 4(10), 2157-2167.

Brinton, D. M., Snow, M. A., \& Wesche, M. B. (1989). Content-based Second Language Instruction. New York: Newbury House Publishers. 
Brinton, D. M., Snow, M. A., \& Wesche, M. B. (2003). Content-based Second Language Instruction. Ann Arbor: The University of Michigan Press. https://doi.org/10.3998/mpub.8754

Corrales, K., \& Maloof, C. (2009). Evaluating the Effects of CBI on an English for Medical Students Program [sic]. Latin American Journal of CLIL, 2(1), 15-23. https://doi.org/10.5294/lacli1.2009.2.1.3

Crandall, J. (1999). Content-based instruction (CBI). Concise Encyclopedia of Educational Linguistics. Oxford, UK: Cambridge University Press.

Davies, S. (2003). Content-based instruction in EFL contexts. The Internet TESL Journal, 4(2).

Doungphummes, N., \& Chandransu, N. (2016). Approaches to Enhance English Communicative Competence of Thai People: A Synthetic Account of Targeted Research Series in English Learning Promotion. Journal of Language and Culture, 35(2), 77-96.

Duenas, M. (2004). The Whats, Whys, Hows and Whos of Content-based Instruction in Second Foreign Language Education. International Journal of English Studies, 4(1), 73-96.

Dupuy. B. C. (2000). Content-based Instruction: Can it Help Ease the Transition from Beginning to Advanced Foreign Language Classes? Foreign Language Annuals, 33(2), 205-222. https://doi.org/10.1111/ j.1944-9720.2000.tb00913.x

Gaffield-Vile, N. (1996). Content-based Second Language Instruction at the Tertiary Level. ELT Journal, 50(2), 108-114. https://doi.org/10.1093/elt/50.2.108

Genesee, F. (1994). Integrating Language and Content: Lessons from Immersion.Educational Practice Report 11. Santa Cruz, CA: National Center for Research on Cultural Diversity and Second Language Learning.

Grabe, W. and Stoller, F. L. (1997). Content-based Instruction: Research Foundations. In M. A. Snow, \& D. M. Brinton (Eds.), The Content-Based Classroom. Perspectives on Integrating Language and Content. White Plains, NY: Addison Wesley Longman.

Hayes, D. (2014). The Value of Learning English in Thailand and its Impact on Thai: Perspectives from University Students. Asia Pacific Journal of Education, 36(1), 73-91. https://doi.org/10.1080/ 02188791.2014.924390

Heo, Y. (2006). Content-based Instruction. TESL Working Paper Series, 4(2), 25-31.

Jaiyai, S., Torwong, P., Usaha, S., Danvirattana, A., Luangthongkam, S., Piyadamrongchai, R., (2005). The Existing Situations and Problems Relating to Foreign Language Teaching and Learning in the Northeastern part of Thailand (Educational Region 5). The Thailand Research Fund.

Jantarach, V. (2009). Drama Activities for Successful English Teaching in Classrooms. Journal of Education Silpakorn University, 6(1,2), 10-21.

Khruawan, P., \& Dennis, N. K. (2017). A study of English Reading Comprehension Using Content-based Instruction Approach. International Journal of Research-Granthaalayah, 5(1), 368-375. https://doi.org/ 10.5281/zenodo.266416

Klee, C. A., \& Tedick, D. J. (1997). The undergraduate foreign language immersion program in Spanish at the University of Minnesota. In S. B. Stryker, \& B. L. Leaver (Eds.). Content-based instruction in foreign language education: Models and methods (pp. 141-173). Washington, DC: Georgetown University Press

Kongkerd, W. (2013). Teaching English in the Era of English Used as a Lingua Franca in Thailand. Retrieved from http://www.bu.ac.th/knowledgecenter/executive_journal/oct_dec.../aw01.pdf

Leaver, B. L., \& Stryker, S. B. (1989). Content-based Instruction for Foreign Language Classroom. Foreign Language Annals, 22(3), 269-275.

Lyster, R. (2007). Learning and Teaching Languages through Content: A Counterbalanced Approach. Amsterdam, NY: Benjamins. https://doi.org/10.1111/j.1944-9720.1989.tb02746.x

Marani, J. S. (1998). An overview of content-based language instruction. (Report No. FL 025 550). (ERIC Document Reproduction Service No. ED 424 762).

Met, M. (1999). Content-based Instruction: Defining Terms, Making Decisions. NFLC Reports. Washington, DC: The National Foreign Language Center.

Napat, W. (2014). Motivational Strategies: Enhancing English Language Skills. Executive Journal, 34(1), 89-97.

Poonpon, K. (2011). Enhancing English Skills through Project-based Learning. The English Teacher, XL, 1-10. 
Punthumasen, P. (2007). International Program for Teacher Education: An Approach To Tackling Problems of English Education in Thailand. The 11th UNESCO-APEID international conference.

Richards, J. C., \& Rodgers, T. S. (2014). Approaches and Methods in Language Teaching (3rd eds.). Cambridge, UK: Cambridge University Press.

Snow, M. A., \& Kamhi-Stein, L. D. (2002). Teaching and Learning Academic Literacy through Project LEAP. In J. A. Crandall, \& D. Kaufman (Eds.), Content-based Instruction in Higher Education Settings. Alexandria, VA: TESOL.

Snow, M. A., Met, M., \& Genesee, F. (1989). A Conceptual Framework for the Integration of Language and Content in Second/Foreign Language Instruction. TESOL Quarterly, 23, 201-217. https://doi.org/10.2307/3587333

Song, B. (2006). Content-based ESL Instruction: Long Term Effects and Outcomes. English for Specific Purposes, 25, 420-437. https://doi.org/10.1016/j.esp.2005.09.002

Srichaiwong, R. \& Maneekul, J. (2017). Development of Content-based Instruction Lessons to Promote English Speaking Ability and Local Knowledge among Matthayomsuksa 6 Students. Journal of Education Naresuan University, 19(3), 253-266.

Stoller, F. L. (2002). Promoting the Acquisition of Knowledge in a Content-based Course. In J. Crandall, \& D. Kaufman (Eds.). Content-based Instruction in Higher Education Settings. Alexandria, VA: TESOL.

Stoller, F. L. (2004). Content-based Instruction: Perspectives on Curriculum Planning. Annual Review of Applied Linguistics, 24, 261-283. https://doi.org/10.1017/S0267190504000108

Stryker, S. B. (1997). The Mexico experiment at the Foreign Service Institute. In S. B. Stryker, \& B. L. Leaver (Eds.). Content-based instruction in foreign language education: Models and methods (pp. 174-199). Washington, DC: Georgetown University Press.

Trakulphadetkrai, N. V. (2011). Thailand: Educational Equality and Quality. In C. Brock, \& L. Pe Symaco (Eds.), Education in South-East Asia. Oxford: Symposium Books.

Walters, S., Gower, R., \& Phillips, D. (2005). Teaching Practice: A Handbook for Teachers in Training. Oxford: Macmillan.

Wesche, M. B. (1993). Discipline-based approaches to language study: Research issues and outcomes. In M. Krueger, \& F. Ryan (Eds.). Language and Content: Discipline- and content-based approaches to language study (pp. 57-79). Lexington, MA: D.C. Heath and Company

Wuthisawangwong, T. (2016). Effects of Content-based Instruction Using Six T'Approach on English Oral Presentation Skills of Lower Secondary School Students. Master's Thesis. Master of Education, Faculty of Education, Chulalongkorn University.

Villalobos, O. B. (2013). Content-Based instruction: A Relevant Approach of Language Teaching. Journal of Innovation Education, 15(2), 71-83. https://doi.org/10.22458/ie.v15i20.515

\section{Copyrights}

Copyright for this article is retained by the author(s), with first publication rights granted to the journal.

This is an open-access article distributed under the terms and conditions of the Creative Commons Attribution license (http://creativecommons.org/licenses/by/4.0/). 